\title{
Examining Gender Inequality in the Sri Lankan Accounting Profession
}

\author{
Yaalini Karunagaran $^{1} \quad$ Dileepa N. Samudrage ${ }^{2^{*}}$ \\ 1.School of Accounting \& Business, The Institute of Chartered Accountants of Sri Lanka, Colombo, Sri Lanka \\ 2.Department of Accounting, University of Sri Jayewardenepura, Nugegoda, Sri Lanka
}

\begin{abstract}
The purpose of this study is to examine the current state of gender inequality in the Sri Lankan accounting profession. Specifically, the study examines whether a glass ceiling (invisible simulated barrier) exists and whether such perception differs based on the gender. Data were gathered through structured questionnaires among 100 accounting professionals. The study found that there is no evidence to support that there is a glass ceiling for women in the accounting field in Sri Lanka. However, the study identified that even though the gender inequality has been reduced, perception on glass ceiling varies between males and females.
\end{abstract}

Keywords: Gender inequality, Glass ceiling, Accounting profession, Sri Lanka.

DOI: $10.7176 / \mathrm{EJBM} / 11-33-02$

Publication date: November $30^{\text {th }} 2019$

\section{Introduction}

According to Sri Lanka Labour force survey, over the decade the female labour participation rate is being increased gradually. However, it is only a marginal improvement and still the female labour force participation rate is less than half the male labour force participation rate. This gender inequality prevails in the labour market where the career path of women has never been that simple. Still women find it harder to get into top managerial positions, in most cases underrepresented in various jobs and get employed in to lower paying jobs. Furthermore, as per the CEOs of Fortune 500 companies of 2018, women just make up to 4.8 percent out of total 500 CEOs with compare to 6.4 percent on 2017.

The annual report of the Central Bank of Sri Lanka, 2018, states that gender gap in the labour force participation has been continued. The female labour force was recorded as 33 percent whereas male labour force recorded as 73 percent for the first quarter of year 2018. This clearly shows the gap between male and female workforce. Despite many gender equality concepts and women empowerment programs in the last two decades, still women are facing gender inequality circumstances in the workplace.

According to the United Nations, human rights are both common to male and female. That means both the males and females should have equal access to resources and opportunities without any bias. Gender equality is essentially an important factor for human development which will then lead to sustainable development.

The annual report of the Central Bank of Sri Lanka 2018 states that Sri Lanka still lags behind in the female participation in the workforce, despite the increasing number of educationally and professionally qualified females. Factors such as issues in marketable skills, narrowed choices in the labour market, gender discriminations related to employment opportunities, wages and promotions, harassment in the workplace and public transport services, unfavourable social norms, unavailability of affordable child care facilities and the multiple social roles and responsibilities expected to be performed by Sri Lankan females, hinder female participation in the workforce. Even the annual report of the Central Bank of Sri Lanka 2016 emphasized when women's participation in the labour force continues to be low, the future economic growth of Sri Lanka would be a challenging one due to inadequate labour force. Contrary to that, gender equality would enhance the economic production and lead to improve social and political systems Bonasso (2013).

Number of studies done in other countries have also shown that still gender inequality exists and it acts as a barrier in the women's career. There had been a very few studies done on this issue considering all sorts of professions in Sri Lanka (Gunawardane, 2016; Gunawardena, 2015). However, there is a dearth of research which has focused on gender inequality especially considering accounting profession in Sri Lanka.

Therefore, this study aims to address three research questions. Firstly, in terms of the Sri Lankan accounting profession, whether a glass ceiling exists and whether such perception differs based on the gender. Secondly, whether there are differences based on gender in career aspirations, work experience, weekly working hours and remuneration. Thirdly, whether based on the gender, the relationship between explanatory factors and the job status differ.

\section{Literature Review}

According to Haynes (2017) the numbers and position of women in accounting has improved over the last 25 years.

\footnotetext{
${ }^{1}$ Yaalini Karunagaran was an undergraduate student at the time of doing this research.
} 
But he stresses that there are some challenges for both women and men at various levels where there is a need for further research.

Gallhofer et al. (2011) examined the voices of female accountants in order to explore how perceived gender roles had an impact on career decisions and work-lifestyle choices. They found that, while structural constraints were evident, many work-lifestyle choices were driven by a desire to spend more time with children, and by women's perceptions of their mothering role. Most women, while recognizing the opportunities forgone, were nonetheless happy with the choices that they had made.

Powell \& Graves (2003) indicates that proportion of women in the labour force as workers and managers has increased throughout the world. But still women find it hard to get into the top managerial positions and employed in lower paying jobs and paid less than that of males for the same job.

Even though the world is accomplishing different gender equality concepts and women empowerment programs, still in society the women are continuing to face gender inequality. Ridgeway (2011) stated that "Gender has many implications for people's lives, but one of the most consequential is that it acts as a basis for inequality between persons".

According to Rigney (2011), this society wires gender roles to kids from their early childhood itself. Girls are encouraged to play with Barbie dolls whereas fire truck is a boy's toy. Males and females are given gender associated toys and are made to dress in a way suitable according to gender. All these early social learning leads to firm views on how members of each gender must behave.

In the study of Gunawardane (2016), according to Sri Lankan Women Partner in Progress, Department of Census \& Statistics of Sri Lanka, out of the total employment status of Sri Lanka, men take up to two thirds of total employment. They have occupied nearly 75 per cent of executive posts and 65 per cent of decision-making positions and thereby job opportunities for women are limited in most of the jobs. He also found that the majority of women are employed in low skill occupations and they still tend to be channeled in to traditionally feminine occupations and to earn less than men even though they perform comparable jobs. On the other hand, gender inequality in the workplace is the concentration of females in low-level jobs and males in high-level jobs. These studies provide evidence that gender inequality not only exists in accounting profession of Sri Lanka, but also visible in other professions as well.

Results of Silva, Magro \& Silva (2016) indicated that glass ceiling exists in the accounting profession and it creates an invisible barrier which prevents women from reaching top managerial positions and jobs with higher pay. Mostly senior positions in accounting and auditing firms are held by males and women do have less visible job position like accounting assistants. Also, job status involving decision making and non-operating are dominated by male professionals.

According to Wirth (2001), glass ceiling is an invisible simulated barrier which is created by attitudinal and organizational prejudice that prevents women from senior managerial positions. Because of such invisible barriers women are being confined into a narrow range of jobs which carries less responsibility and lower pay, where there are only few opportunities available for the career growth.

The study of Bruce-Twum (2013) examined the accounting profession and female gender in Ghana and observed that no any women from the sample of his study were in the top positions in their respective jobs. Even in the audit firms, it was very rare to see females in the partner status.

Silva, Magro, Gorla \& Silva (2018) found that the highest positions in the accounting profession and auditing field were occupied mainly by male professionals and entry difficulties of women into the accounting profession also persist. Furthermore, the study added that difference in pay was observed, as men receive higher remunerations than women in similar functions.

Even the study of Ramdhony, Oogarah-Hanuman \& Somir (2013) examined the presence of women in the three big accounting firms and found that the accounting profession in Mauritius is mostly male dominated. Women are underrepresented in senior accounting positions where the percentage of males achieving managerial positions being considerably higher than that of females. The findings indicate that still glass ceiling effect exists in the accounting profession, whereby corporate practice and prejudice seem to block access to the top for women.

Ud-Din, Cheng \& Nazneen (2018) examined the effects of organizational culture, society, and masculinity on women's skills in accounting workplaces and the influences of workplace norms, culture, and organizational structure on women's leadership qualities and behaviours towards their work. They concluded that women's career progress is still oppressed in the accounting workplaces worldwide. They also pointed out that occupational segregation worsens gender inequality, which discourages women from entering male-dominated jobs because such jobs are believed to need either body strength to perform the job with uninterrupted working hours or are female dominated jobs that are feminized work.

Furthermore, Silva et al. (2016) added that there is a predominance of accounting male professionals in large companies and female professionals in small and medium-sized businesses, and men tend to stay longer in positions of the accounting profession in the same company. Women who tend to have high job status are delaying their marriage or child birth or having few children. Women have more accomplishments when they have less 
domestic responsibilities because such responsibilities can lower their organizational commitment. Finally, the study stated that the existence of glass ceiling influences on the increased difficulty of access for women in key positions in the accounting profession. Thereby the study concluded that the occurrence of gender inequalities and the glass ceiling effect were found in the accounting profession.

Hoddinott \& Jarratt (1998) studied about gender bias in the public accounting profession of Australia. According to the study men reach higher employment positions faster than women. Thereby men are having quicker growth in their career and in salary level too higher than that of women.

The study of Obeid (2016) found that women are underrepresented in the top managerial positions even though they possess all the attributes of top management. It also added that men are favored in senior management positions and this has impacted on career progression of women. Majority of the women in Khartoum-Sudan believe that the glass ceiling effect still exists, and it is creating discriminatory barriers for women in the accounting profession.

Rowe (2014) investigated gender bias in the accounting profession to determine if gender bias was present in the accounting profession and to explore the nature and extent of the differences between men in women with respect to activities used to advance their public accounting careers. The results suggest that gender bias among Mississippi public accountants is not as pervasive as past studies would suggest.

Findings of Whiting \& Wright (2001) indicate that female accountants of New Zealand on average receive less remuneration than male counterparts and it is because of their lower job status. Reasons given for such differences include males having more work experience, their ability to work for longer hours, high career aspirations and personal attributes, lower levels of responsibility for their dependent children and less discrimination. On the other hand, females have less career advancement ambitions since they have more responsibility towards their dependent children and family.

According to Greene \& Smith's (2015) study, still women are facing discrimination. This discrimination has taken many forms like women not included in certain types of work, salary and wage disparities, where women are paid less for the same work done as males. So, this discrimination is a reason for the glass ceiling. Moreover, these barriers are purely due to gender and not because of any inability of women to occupy such high job positions.

Arford \& Bennett (2012) have stated that lack of visible female mentors and role models is also a contributor for the barrier. Lack of female mentors and role models in the accounting profession depicts the male domination. This has weakened female accountants' confidence, their sense of belonging to the profession and hindered their career advancement though they have promising potentials that can take them for executive levels.

Literature has also identified that gender stereotyping is also serving as one of the barriers for women's career advancement. Study of Katrinli, Gunay, Acar \& Karaibrahimoglu (2010) examined the occupational gender stereotyping in the accounting profession in Turkey. Survey was conducted with undergraduate students of Business Administration Department of Izmir University of Economics in Turkey and with non-student individuals using snowball sampling technique. The study concluded that occupational gender role stereotype exists in the accounting profession of Turkey and the profession is largely male dominated.

Furthermore, Ud-Din et al. (2018) have stated that world female employment at the tertiary level is increasing, but female participation in the industry is decreasing. They argued that three factors influence career progress at accounting firms. First factor is that nineteenth-century perceptions about women's careers persist. Second, most women are victim blaming- women are oppressed and are not able to change "traditional ideas". Third, many accounting associations are male-dominated, rules and regulations are formulated by men, which might overlook women's leadership qualities in addition to failing to offer an environment in which women may thrive. Also stated that the essence of traditional patriarchy in these associations persists, although it is invisible.

Findings of Obeid (2016) showed some social and cultural barriers. They are stereotype attitude, family responsibilities, personal life and motherhood. Majority of the respondents stated that barriers to their career progression are due to stereotype attitude in certain organizations. Women are perceived that they are weak, and they cannot handle tireless accounting jobs. Women find it difficult to manage their professional life and family responsibility along with motherhood. Additionally, the study also found that maintaining a balance between them leads to frustration as female accountants have to meet a lot of commitments. This is also supported by the studies of Dambrin \& Lambert (2008), where states that in audit firms of France, when women enter parenthood it acts as an obstacle to cross their career paths in auditing.

But there were mixed evidences as well. Flynn, Earlie \& Cross (2015) investigated gender inequality in the accounting profession of Ireland. The participants of the study denied the existence of glass ceiling and told that profession has progressed, and now it is they who have to get their job done, and thereby rewards and promotion will follow them. Some respondents of the study added that glass ceiling is not relevant to accounting profession and opportunities are equally available to both the genders. Furthermore, it was asserted that glass ceiling was selfimposed, and it only existed in the minds of women.

In the analysis of Catalyst (2016) in USA it was found that 63 percent of all accountants and auditors in the United States are women. Furthermore, women represent 47 percent of all professional staff at Certified Public 
Accountant (CPA) firms. In addition, it was found that the percentage of women on management committees has increased, that is 23 percent of women in 2015 compared to 17 percent in 2011 . Furthermore, women have made up to 47 percent of senior managers in 2015 when compared to 38 percent in 2011.

In addition to above findings, Nasman \& Olsson (2018) studied gender inequalities in accounting and auditing businesses of Sweden. The data for the study has been collected among auditors and accountants all over Sweden through surveys which were sent via email. They have identified that most job positions are gender balanced and concluded that no overall glass ceiling theory being in effect in Sweden's current accounting and auditing field.

The authors observed that there are contradictory findings regarding gender inequality in the accounting profession. Certain studies state that gender inequality still prevails in the accounting profession whereas certain studies disagree with the findings. The favouring studies state that glass ceiling exists in the accounting profession and it creates an invisible barrier which prevents women from reaching top managerial positions and jobs with higher pay.

As discussed in the literature review, majority of studies in gender inequality were done in foreign contexts. Further, it was evident that there were very limited studies which examined gender inequality in Sri Lanka. Also, those studies have focused on all professions in general in Sri Lanka (Gunewardene, 2016; Gunewardena, 2015). The researchers have not come across any study which has focused especially on the accounting profession in Sri Lanka and it is apparent that a knowledge gap exists in this specific research area. Therefore, this study focusses mainly on the examination of the gender inequality in the Sri Lankan accounting profession.

\section{Methodology}

\subsection{Research Approach}

A quantitative approach was undertaken to collect data about perceptions of Sri Lankan accounting professionals regarding their career progression, the glass ceiling and gender related barriers. This approach was commonly used in previous studies as well (Flynn, et.al., 2015; Whiting \& Wright, 2001).

\subsection{Data Collection}

Data were collected through both primary and secondary sources. Under the primary source, mainly a structured questionnaire was distributed among accounting professionals in both audit and non-audit firms. In addition to the questionnaire survey, few interviews with senior managers were carried out. Further, secondary sources like Central Bank Annual report of Sri Lanka, gender inequality index and other documentary evidences were used. The questionnaire was adopted from the article Whiting \& Wright (2001). Since the questionnaire was not available online or in any other source, an email was sent to the authors of the article requesting the original questionnaire that was used for their study. In order to review the applicability and relevance of the questionnaire to the local context, the expert opinions of two senior academics were sought, and the questionnaire was modified accordingly. Thereafter, a pilot survey was conducted among the colleagues of the researchers in order to receive further feedback on the length, readability and quality of the questionnaire. Finally, the questionnaire was modified and circulated among the accounting professionals via paper based as well as online.

\subsection{Sample}

The sample of this study comprises of accounting professionals from non-audit firms and audit firms. Total of 100 respondents responded to the questionnaire. The study sample consists of both male and female accounting professionals. Thereby both the genders view points and perceptions were studied. The study was conducted in Colombo district and suburbs of Sri Lanka due to the fact that most of the audit firms and commercial companies are located in this area.

\subsection{Operationalization of Variables}

Operationalization of variables are illustrated in Table 1. 
Table-1: Operationalization of Variables

\begin{tabular}{|l|l|l|}
\hline Variable Type & \multicolumn{1}{|c|}{ Variable } & \multicolumn{1}{c|}{ Measurement } \\
\hline \multirow{5}{*}{ Qualifications } & $\begin{array}{l}\text { Highest tertiary qualification held; Professional qualifications } \\
\text { held }\end{array}$ \\
\cline { 2 - 3 } factors & Work experience & Number of years employed in the accounting profession \\
\cline { 2 - 3 } & $\begin{array}{l}\text { Proportion of time spent } \\
\text { out of the profession }\end{array}$ & $\begin{array}{l}\text { Time out (months/ years) as a percentage of total accounting } \\
\text { career length (years) }\end{array}$ \\
\cline { 2 - 3 } & Working hours per week & Average number of hours spent in working per week \\
\cline { 2 - 3 } & Family responsibility & Number of dependent children; \\
\cline { 2 - 3 } & Personal attributes & $\begin{array}{l}\text { Primary care given for children out of school/ nursery and } \\
\text { elderly parents }\end{array}$ \\
\cline { 2 - 3 } & $\begin{array}{l}\text { Self-confidence; Competitiveness; Decisiveness; Leadership } \\
\text { abilities; Desire for responsibility; Ability to handle pressure }\end{array}$ \\
\cline { 2 - 3 } & Career aspirations & Level of employment aspired \\
\cline { 2 - 3 } & Mobility & Number of times relocated to get promoted \\
\cline { 2 - 3 } & $\begin{array}{l}\text { Level of mentor support } \\
\text { received }\end{array}$ & $\begin{array}{l}\text { Level of mentor support received by the participant in his/her } \\
\text { career }\end{array}$ \\
\cline { 2 - 3 } & Discrimination & $\begin{array}{l}\text { Level of discrimination received in their career as an } \\
\text { accountant }\end{array}$ \\
\hline \multirow{5}{*}{$\begin{array}{l}\text { Dependent } \\
\text { variables }\end{array}$} & Job status & Level of position currently held \\
\cline { 2 - 3 } & Salary & Gross monthly salary received \\
\hline
\end{tabular}

Source: Whiting \& Wright (2001)

\subsection{Conceptual Framework}

The conceptual framework used in this research is displayed in Figure 1.
Explanatory factors
- Qualifications
- Work Experience
- Proportion of time out of total career
- Working hours per week
- Family responsibility
- Personal attributes
- Career aspirations
- Mobility
- Level of mentor support received
- Discrimination
- Mobility

Figure 1: Conceptual Framework (Source: Whiting \& Wright (2001))

\subsection{Data Analytical Strategies}

In order to analyze the data, Statistical Package for the Social Sciences (SPSS) was used. Primarily, descriptive statistics were used to analyze the demographic data. Furthermore, in order to examine whether a glass ceiling exists a one sample $t$-test was performed. Furthermore, to examine whether such glass ceiling perception differ based on the gender or not, independent samples $t$-test (also known as two-sample $t$-test) was employed. It was used to highlight any differences in the perception between males and females on the existence of glass ceiling.

In addition, to observe whether there are differences in career aspirations, work experience, weekly working hours, and remuneration by gender, adjusting for job status, Mann Whitney u test was done. Finally, to examine whether based on the gender the relationship between the selected explanatory factors and the job status differ, Spearman's correlation was used. 


\section{Findings and Discussion}

\subsection{Descriptive Statistics}

Of the 100 respondents participated in this study, 52\% were females while $48 \%$ were males. In respect of the educational and professional qualifications, $23 \%$ had General Certificate of Education (G.C.E.) Advance Level as their basic academic qualification and $11 \%$ of the participants had Master's as their highest academic qualification. Professional qualifications wise 42 participants have Chartered Accountants of Sri Lanka (CA Sri Lanka) qualification, 21 participants are qualified in Association of Chartered Certified Accountants (ACCA) whereas 24 participants have Chartered Institute of management Accountants (CIMA) qualification. 52\% of the participants are from non-audit firms whereas $48 \%$ from audit firms.

Out of the 100 participants, $83 \%$ were currently employed in accounting field and rest of the $17 \%$ currently employed in non-accounting field. In terms of the experience in the accounting or audit field, $82 \%$ had $1-5$ years' experience, $11 \%$ had 6-10 years' experience, $5 \%$ had $11-15$ years' experience and a mere of $1 \%$ each in $16-20$ and 21-25-years' experience.

\subsection{Examining whether a glass ceiling exists}

In order to examine whether a glass ceiling exists in the accounting profession in Sri Lanka, the researchers used eight statements as stated below. Responses received for those questions were used in the analyses performed in this section.

S1: Some people say there is an invisible barrier or a "glass ceiling" that hinders or excludes women from advancement to upper management positions. I believe that gender barriers generally exist in today's Sri Lankan Accounting field.

S2: I believe that a glass ceiling exists in my company.

S3: In my company, women are primarily encouraged to apply for support roles rather than operational, technical, and general management positions.

S4: In my company, there are equal career development opportunities for both men and women.

S5: In my company, women have advanced into senior management positions.

S6: In my company, I have been considered for and denied a promotion based on my gender.

S7: I believe my company structure and practices favour male employees.

S8: In my company, management has established anti-discrimination practices.

4.2.1 One sample t-test

A one-sample $t$-test was used to assess whether the respondents perceive the existence of a glass ceiling for women in the accounting field in Sri Lanka. One-sample $t$-test was used to compare the mean value of the sample with the mid-point of the variable (also known as the "Test value"), which is 3 in this analysis. Accordingly, two hypotheses were proposed as below.

$\mathrm{H}_{0}$ : Mean of the sample is equal to the mid-point of 3 .

$\mathrm{H}_{1}$ : Mean of the sample is not equal to the mid-point of 3 .

Table-2: One Sample t-test

\begin{tabular}{|c|c|c|c|c|c|c|}
\hline & $\mathrm{N}$ & Mean & $\mathrm{T}$ & $\mathrm{df}$ & $\begin{array}{c}\text { Sig. } \\
\text { (2-tailed) }\end{array}$ & $\begin{array}{c}\text { Mean } \\
\text { Difference }\end{array}$ \\
\hline $\begin{array}{l}\text { Average of glass } \\
\text { ceiling variables }\end{array}$ & 100 & 3.0400 & .645 & 99 & .521 & .04000 \\
\hline
\end{tabular}

Test Value $=3$

Source: Survey data

Results are shown in Table 2. Results reveal that the sample mean is 3.04, which is slightly above the midpoint of 3 . However, since $p>0.05$, it is evident that the sample mean is not significantly different from the mid-point. Hence, we accept the null hypothesis. We can conclude that there is no evidence to support that there is a glass ceiling for women in the accounting field in Sri Lanka. This finding is consistent with those of previous studies by Nasman \& Olsson (2018), Catalyst (2016), Flynn, et. al. (2015) which confirmed that there was no overall glass ceiling being in effect in accounting profession.

During the interviews a senior manager in a non-audit firm also confirmed above finding by stating that:

'I think our society has developed and most of the organizations are giving equal chances to both genders without any biasness. It's you who have to develop your skills, get yourself qualified and get good exposure and get yourself experienced to survive yourself in this competitive world'.

4.2.2 Independent sample t-test for each glass ceiling statements

The researchers performed an independent samples $t$-test to examine whether male and female accounting professionals differ in their perceptions on the existence of a glass ceiling. Table 3 presents the results. The results show that except for the two statements S4 and S5, the answers significantly differ $(\mathrm{p}<0.05)$ between males and females. Mean values indicate that in most of the instances the females tend to believe more compared to their 
male counterparts that there is glass ceiling for them. This is consistent with the findings of Obeid (2016); Gunawardane (2016); Silva, Magro \& Silva (2016); Greene \& Smith's (2015) and Gallhofer et al. (2011) where they found that most of women participants of the study believed that the glass ceiling effect still existed, and it was creating discriminatory barriers for women in the accounting profession.

Table-3: Independent sample t test- for each glass ceiling variable based on gender

\begin{tabular}{|c|c|c|c|c|c|c|}
\hline Glass ceiling variables & Gender & $\mathbf{N}$ & Mean & Std. Deviation & Significance & Mean Difference \\
\hline \multirow[t]{2}{*}{$\mathrm{S} 1$} & Male & 48 & 2.94 & 1.156 & \multirow[b]{2}{*}{.000} & \multirow[b]{2}{*}{-1.043} \\
\hline & Female & 52 & 3.98 & .918 & & \\
\hline \multirow[t]{2}{*}{ S2 } & Male & 48 & 2.73 & 1.067 & \multirow{2}{*}{.000} & \multirow{2}{*}{-.732} \\
\hline & Female & 52 & 3.46 & .828 & & \\
\hline \multirow[t]{2}{*}{$\mathrm{S} 3$} & Male & 48 & 2.54 & .922 & \multirow{2}{*}{.003} & \multirow{2}{*}{-.574} \\
\hline & Female & 52 & 3.12 & .983 & & \\
\hline \multirow[t]{2}{*}{ S4 } & Male & 48 & 3.44 & .965 & \multirow{2}{*}{.105} & \multirow{2}{*}{.303} \\
\hline & Female & 52 & 3.13 & .886 & & \\
\hline \multirow[t]{2}{*}{ S5 } & Male & 48 & 3.48 & 1.031 & \multirow{2}{*}{.113} & \multirow{2}{*}{.306} \\
\hline & Female & 52 & 3.17 & .879 & & \\
\hline \multirow[t]{2}{*}{ S6 } & Male & 48 & 2.04 & 1.110 & \multirow{2}{*}{.000} & \multirow{2}{*}{-.901} \\
\hline & Female & 52 & 2.94 & .873 & & \\
\hline \multirow[t]{2}{*}{ S7 } & Male & 48 & 2.88 & 1.196 & \multirow{2}{*}{.007} & \multirow{2}{*}{-.606} \\
\hline & Female & 52 & 3.48 & 1.000 & & \\
\hline \multirow[t]{2}{*}{$\mathrm{S} 8$} & Male & 48 & 2.44 & 1.109 & \multirow{2}{*}{.029} & \multirow{2}{*}{.438} \\
\hline & Female & 52 & 2.00 & .863 & & \\
\hline
\end{tabular}

Significant at the 0.05 level (2 tailed)

$\mathrm{N}=100$

Source: Survey data

4.2.3 Independent samples t-test on average glass ceiling statements

Another analysis focused on considering all eight statements, which measured the existence of a glass ceiling, together to see the answers differ between males and females. The result of the independent samples $t$-test is shown in Table 4. The results clearly indicate that the perception on the existence of a glass ceiling significantly differs between males and females $(\mathrm{p}<0.05)$. Mean values of females are above 3 indicating their belief in relation to the existence of a glass ceiling, while males seem otherwise (mean for males $<3$ ). Even in the studies of Flynn, et. al. (2015), most of the females acknowledged the existence of a glass ceiling, whereas majority of the males disagreed. Thereby gender polarization can be seen among the viewpoints.

Table-4: Independent sample $t$ test on average glass ceiling

\begin{tabular}{|c|c|c|c|c|c|}
\hline Gende & & $\mathrm{N}$ & Mean & Sig.(2-tailed) & Mean difference \\
\hline \multirow[t]{2}{*}{$\begin{array}{l}\text { Average of glass } \\
\text { ceiling variables }\end{array}$} & Male & 48 & 2.7214 & \multirow[t]{2}{*}{.000} & \multirow[t]{2}{*}{-.61278} \\
\hline & Female & 52 & 3.3341 & & \\
\hline
\end{tabular}

Significant at the 0.05 level (2 tailed), $\mathrm{N}=100$

Source: Survey data

4.3 Analysis of the differences in career aspirations, work experience and weekly working hours

The Mann Whitney U test was used to analyse the differences in career aspirations, work experience and weekly working hours by gender, adjusting for job status. Results are shown in Table 5. The analysis was carried out by dividing the current sample into three job categories, as illustrated below. 
Table-5: Analysis of the differences in career aspirations, work experience and weekly working hours by gender, adjusting for job status

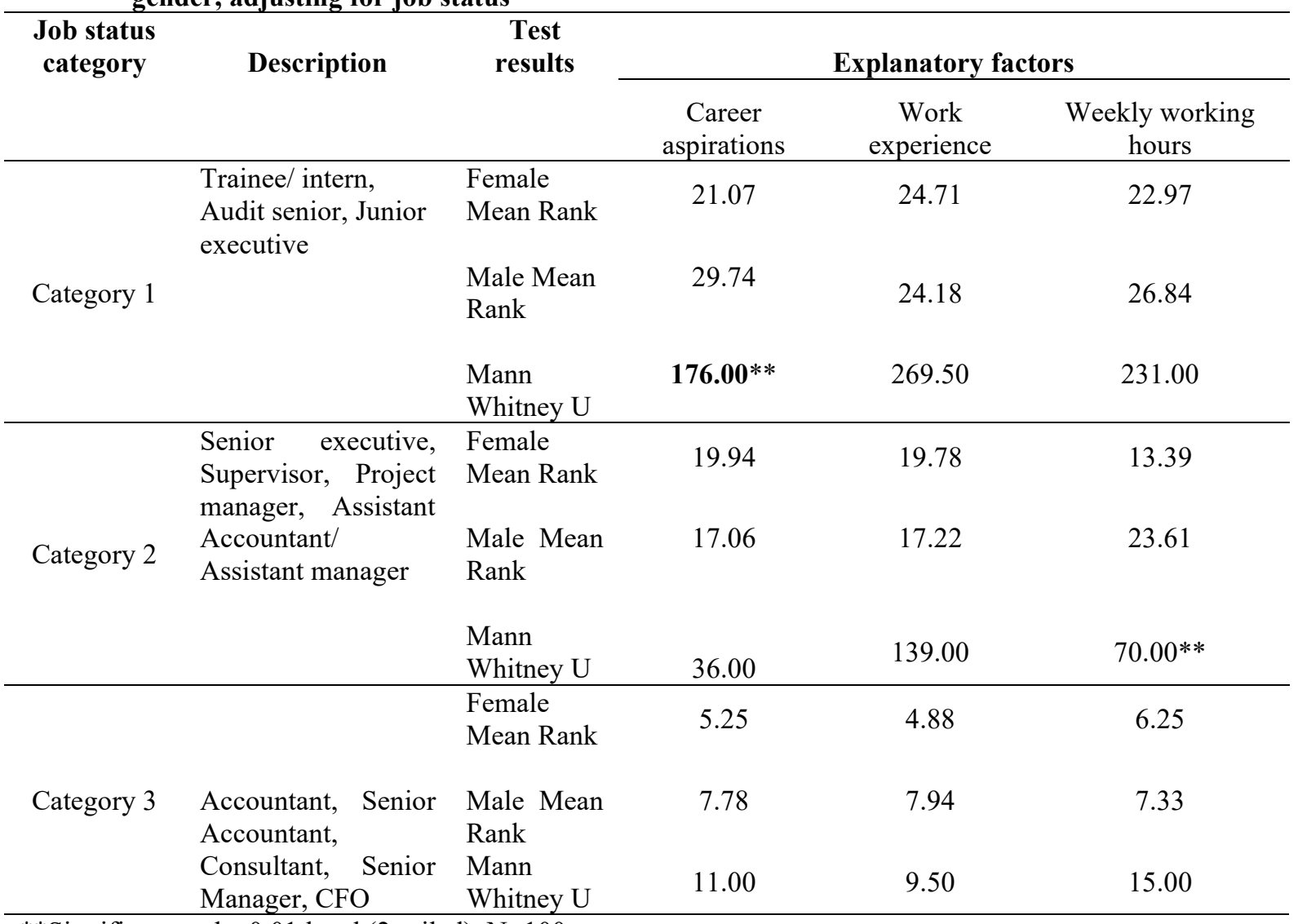

**Significant at the 0.01 level (2-tailed), $\mathrm{N}=100$

Source: Survey data

In category 1, respondents show no differences in work experience and weekly working hours. But there is a statistically significant difference $(\mathrm{p}<.05)$ in career aspirations between females and males. Under category 2 , respondents show no differences in work experience and career aspirations. But there is a statistically significant difference $(\mathrm{p}<.05)$ in average weekly working hours between females and males. And in the final category 3 , the respondents showed no differences in career aspirations, hours worked and work experience between females and males.

Amongst the employees in category 1, females tend to have less career aspirations in their initial stage of work. This is mainly due to lack of motivation and empowerment provided to women when they start to work. This was supported by a comment made by one audit senior from an audit firm:

'Being a girl, I have met so many barriers. In the initial stage when I started working and when I do get late to come back home after work, my parents and relatives were so concerned and scared. Most of my relatives have discouraged me too. Since in audit firms, you have to work late and go to many places. I have faced so much of discouragements. So, because of these I just thought to complete my internship requirement and leave the job, thereby my career aspiration wasn't there'.

Another senior executive in a non-audit firm further proved this situation stating that:

"My ambition or career growth is not important as my children and family because I believe sacrificing my career would help my children to succeed in their lives as professionals which would give me more satisfaction than my achievements"

This was further confirmed by Gallhofer et.al. (2011) stating that most women, while recognizing the opportunities forgone, were nonetheless happy with the choices that they had made.

Amongst the employees in category 2, female respondents who were married and had children were the ones who had mostly contributed to the difference in working hours. A comment by a senior executive in a non-audit firm supports this idea:

'Before motherhood, I was able to stay late and work for my deadline. But after giving birth, I was unable to spend more time in my job since I have more family responsibilities. Have to go early to take care of my kid. When he becomes sick or any emergency arises, I have to take leave and look after him. So, these affected my career life. I had a tough time in balancing work and family life'. 
Haynes (2017) findings also noted that even though accounting as a historically masculine profession it has opened its doors to women in large numbers but many challenges remain involving gendered career hierarchies; interaction with motherhood; work-life issues and choices, and feminization and segmentation in the profession.

Findings of Obeid (2016) also support the fact that women find it difficult to manage their professional life and family responsibility along with motherhood. This is also supported by the studies of Dambrin \& Lambert (2008), where they state that in audit firms in France, when women enter parenthood it acts as an obstacle to cross their career paths in auditing. Gammie \& Whiting (2013) suggest that the primary reason women leave professional accountancy firms is to seek more interesting work as opposed to obtaining more flexibility in their working lives. According to the study done by Toffanin (2009), there is a significant inequality between men and women in their work-life balancing perspective. It further states that in Italy, the amount of time committed to domestic work is the most obvious element of gender inequality in the use of daily time. Women's employment rate is influenced by the domestic and care work and it usually depends on partners' sharing of care responsibilities.

4.4 Analyzing the differences in remuneration based on gender, controlling for job status

The Mann Whitney U test was used to analyse the differences in remuneration between males and females, adjusting for job status. Results are shown in Table 6 . The analysis was carried out by dividing the current sample into three separate job categories, which was identified in 4.3 above.

Table-6: Analyzing the differences in remuneration by gender, adjusting for job status

\begin{tabular}{ccccc}
\hline Job status category & Gender & Respondents & Mean Rank & Mann Whitney U \\
& & & & \\
\hline \multirow{2}{*}{ Category 1 } & Female & 29 & 25.16 & 256.500 \\
& Male & 19 & 23.50 & 146.500 \\
\hline \multirow{2}{*}{ Category 2 } & Male & 18 & 19.36 & 8.500 \\
& Female & 18 & 17.64 & \\
\hline \multirow{2}{*}{ Category 3 } & Female & 4 & 8.63 & \\
\hline
\end{tabular}

\section{Source: Survey data}

According to the results shown in Table 6 , it is evident that there is no statistically significant salary difference between males and females within the three job categories. In other words, the results do indicate that without any gender inequality, both men and women are being paid for how they perform. The distribution of gross monthly remuneration is similar across categories of jobs, irrespective of the employee's gender. But this result contrasts with past studies such as Whiting \& Wright (2001) and Hoddinott \& Jarrat (1998), where those studies showed that men, on average, received a higher salary than women in senior levels even though they perform equivalent jobs.

\subsection{The relationship between selected explanatory factors and the job status}

Spearman's rank correlation coefficient (also known as Spearman's rho) was calculated to determine the relationship between selected explanatory factors and job status. Results of the correlation analysis related to males are shown in Table 7 and females are shown in Table 8.

As per the Table 7, of the ten factors studied, job status has a positive and significant relationship with professional qualification of CASL, work experience, career aspirations, working hours, family responsibility, and ability to handle pressure. Amongst those factors, job status seems to have stronger relationships with work experience and professional qualifications of CASL (where correlation coefficient is above 0.7), and moderate relationships career aspirations and working hours (where correlation coefficient is between 0.4 and 0.69 ).

However, according to Table 7, the relationship job status has with Family responsibility and Ability to handle pressure is weak (where correlation coefficient is between 0.2 and 0.39). Hence, it can be inferred that males with higher work experience and higher qualifications of CASL have a greater chance in receiving higher job status. 
Table-7: Correlation analysis for male participants for the relationship between selected explanatory factors and the job status

\begin{tabular}{lc|c}
\hline & \multicolumn{2}{c}{ Spearman's Rank correlation } \\
\cline { 2 - 3 } & Spearman's rho & Significance \\
\hline Qualifications & & 0.08 \\
Highest academic qualification & 0.26 & $\mathbf{0 . 0 0}$ \\
Professional qualification CASL & $\mathbf{. 7 1 1 ^ { * * }}$ & 0.48 \\
Professional qualification ACCA & -0.36 & 0.05 \\
Professional qualification CIMA & 0.53 & $\mathbf{0 . 0 0}$ \\
\hline Work experience & $\mathbf{. 7 8 8 ^ { * * }}$ & 0.43 \\
\hline Time out in total for the above break & -0.27 & 0.26 \\
\hline Mobility & 0.17 & $\mathbf{0 . 0 0}$ \\
\hline Career aspirations & $\mathbf{. 5 9 9 * *}$ & 0.57 \\
\hline Level of mentor support & -0.08 & 0.29 \\
\hline Discrimination & -0.15 & 0.07 \\
\hline Personal attributes & & 0.93 \\
Self Confidence & 0.26 & 0.10 \\
Competitiveness & -0.01 & 0.14 \\
Decisiveness & 0.24 & 0.64 \\
Leadership qualities & 0.21 & $\mathbf{0 . 0 3}$ \\
Desire for responsibility & 0.07 & $\mathbf{0 . 0 1}$ \\
\hline Ability to handle pressure well & $\mathbf{3 1 9 *}$ & $\mathbf{0 . 0 3}$ \\
\hline Working hours & $\mathbf{3 7 0}$ & $\mathbf{. 4 6 6 *}$ \\
\hline
\end{tabular}

*. Correlation is significant at the 0.05 level (2-tailed)

**. Correlation is significant at the 0.01 level (2-tailed)

Source: Survey data

As per Table 8, of the ten factors studied, job status has a positive and significant relationship with work experience, professional qualification of ACCA, career aspirations, working hours, and family responsibility.

Amongst the factors identified in Table 8, job status seems to have moderate relationships with work experience, professional qualification of ACCA, career aspirations, and working hours (where correlation coefficient is between 0.4 and 0.69). Therefore, it can be inferred that female employees may have a chance of going to upper positions of their jobs by focusing more on those four factors. However, the relationship between job status and Family responsibility is weak (where correlation coefficient is between 0.2 and 0.39 ). 
Table-8: Correlation analysis for female participants for the relationship between selected explanatory factors and the job status

\begin{tabular}{lc|c}
\hline & \multicolumn{2}{c}{ Spearman's Rank correlation } \\
\cline { 2 - 3 } & \multicolumn{1}{c}{ Spearman's rho } & Significance \\
\hline Qualifications & & 0.05 \\
Highest academic qualification & 0.27 & 0.08 \\
Professional qualification CASL & 0.42 & $\mathbf{0 . 0 2}$ \\
Professional qualification ACCA & $\mathbf{. 6 0 8}$ & 0.44 \\
Professional qualification CIMA & -0.27 & $\mathbf{0 . 0 0}$ \\
\hline Work experience & $\mathbf{. 6 6 5}$ & 0.30 \\
\hline Time out in total for the above break & 0.24 & 0.09 \\
\hline Mobility & 0.24 & $\mathbf{0 . 0 0}$ \\
\hline Career aspirations & $\mathbf{. 5 8 8 ^ { * * }}$ & 0.25 \\
\hline Level of mentor support & -0.16 & 0.67 \\
\hline Discrimination & 0.06 & 0.41 \\
\hline Personal attributes & & 0.36 \\
Self Confidence & -0.12 & 0.65 \\
Competitiveness & 0.13 & 0.79 \\
Decisiveness & 0.06 & 0.80 \\
Leadership qualities & -0.04 & 0.74 \\
Desire for responsibility & -0.04 & $\mathbf{0 . 0 1}$ \\
Ability to handle pressure well & -0.05 & $\mathbf{0 . 0 1}$ \\
\hline Family responsibility & $\mathbf{3 3 6 *}$ & $\mathbf{. 5 5 6 *}$ \\
\hline Working hours & & \\
\hline Corran & & \\
\hline
\end{tabular}

*. Correlation is significant at the 0.05 level (2-tailed)

**. Correlation is significant at the 0.01 level (2-tailed)

Source: Survey data

\section{Conclusion}

This study provides an understanding on the current situation of gender inequality and the existence of glass ceiling in the accounting profession in Sri Lanka and the factors that cause the invisible barrier.

The findings of this study disclosed a different view of gender inequality with compared to studies done in the past, which had emphasized the existence of gender inequality. This study confirmed that there is no overall glass ceiling in accounting profession in Sri Lanka. Further, this study identified that even though gender inequality is reduced, perception on glass ceiling still exists and perception about glass ceiling varies between males and females. In addition to that study revealed that there are positive movements towards remuneration and job status equality between male and female. Females have shown growth in work experience, working hours and career aspirations unlike previous decades.

The findings of this study would help the policy makers of the country and the managers of organizations. Especially the accounting field organizations should design policies to encourage women to participate in the accounting profession with more flexible terms such as work from home, flexible working hours and equal opportunities to get proper exposure in the work environment.

Even though Government of Sri Lanka has recognized the requirement to overcome the issue of low rate involvement amongst females in the country, its concentration has not been focused on tackling the cultural beliefs, norms and practices prevail in the country that continue to hold women back. If Sri Lanka is anticipating tapping into the dynamic potential those women hold, the Government of Sri Lanka should look forward to modify the general attitude existing towards women's responsibilities and involvements in the labour force. It must also develop and introduce certain mechanisms to encourage and support those women who endure to function within existing socio-cultural background.

Furthermore, Sri Lanka should consider about introducing national level policies on gender equality and nondiscrimination, including zero acceptance for sexual harassment, encouraging working measures, such as flexible working hours and work from home facilities and support services like reasonable and high-quality child and elder care facilities and safe mode of transportation. These initiatives will have a noteworthy impact on increasing the 
female participation in the labour force and increasing labour force participation rate as a whole, which would, in turn, contribute to the country's economic growth.

\section{References}

Annual Report Central Bank of Sri Lanka, 2016.

Annual Report Central Bank of Sri Lanka, 2018.

Arford, F., \& Bennett, M. (2012). The state of women in the accounting profession. Accounting Today, Voices.

Bruce-Twum, E. (2013). The Accounting Profession and the Female Gender in Ghana. Accounting and Finance Research, 2(1), 54-60.

Bonasso, D. (2013). Gender equality and the developing world. (Blog post). Retrieved from https://borgenproject.org/gender-equality-important-developing-world/

Catalyst. Quick Take: Women in Accounting. New York: Catalyst, 2016.

Dambrin, C., \& Lambert, C. (2008). Mothering or Auditing? The Case of Two Big Four in France. Accounting, Auditing and Accountability, 21(4).

Greene, B. M., \& Smith, R. A. (2015). Gender inequality in the workplace. Columbia University Academic Commons. Retrieved on September 20 ${ }^{\text {th }}, 2017$ from https://doi.org/10.7916/D8TB16FM.

Flynn, A., Earlie, E. K., \& Cross, C. (2015). Gender equality in the accounting profession: one size fits all. Gender in management: An international journal, 30(6), 479-499.

Gammie, E., \& Whiting, R. (2013). Women accountants: is the grass greener outside the profession? British Accounting Review, 45(2), 83-98.

Gallhofer, S., Paisey, C., Roberts, C. \& Tarbert, H. (2011), "Preferences, constraints and work-lifestyle choices", Accounting, Auditing \& Accountability Journal, $\quad$ Vol. $24 \quad$ No. $\quad 4, \quad$ pp. 440470. https://doi.org/10.1108/09513571111133054

Gunawardane, D.S.W. (2016). Gender Inequality in Sri Lanka. Felicitation Volume of Senior Professor Prema Podimenike, 64-81. Retrieved October 11th,2017, Accessed: http://repository.kln.ac.lk/handle/123456789/12052

Gunawardena, N. S. (2015). Women in Sri Lanka. Journal of the college of community physicians of Sri Lanka, 20(1), 4-25. Retrieved October $11^{\text {th }}, 2017$, Accessed: http://doi.org/10.4038/jccpsl.v20i1.8067

Haynes, K. (2017). Accounting as gendered: A review of 25 years of critical accounting research on gender. Critical perspectives on Accounting, 43, 110-124.

Hoddinott, M., \& Jarratt, D. G. (1998). Gender imbalance in the workforce: an examination of the public accounting profession. Australian Accounting Review, 8(2), 59-67.

Katrinli, A., Gunay, G., Acar, E. E., \& Karaibrahimoglu, Y. (2010). Gender Stereotyping in the Accounting Profession in Turkey. Journal of Modern Accounting and Auditing, 6(4), 15-25.

CEOs of Fortune 500 companies. Retrieved October $24^{\text {th }}, 2018$, Accessed: https://www.cnbc.com/2018/05/21/2018s-fortune-500-companies-have-just-24-female-ceos.html

Nasman, L. L., \& Olsson, M. (2018). Gender inequalities in Accounting and Auditing Businesses. Umeå University, Sweden. Retrieved October 15th, 2019, Accessed: http://umu.divaportal.org/smash/get/diva2:1225309/FULLTEXT01.pdf

Obeid, A. (2016). "Women in accounting profession" The barriers and challenges. International Journal of Economics, Commerce and Management, 4(5), 503-511.

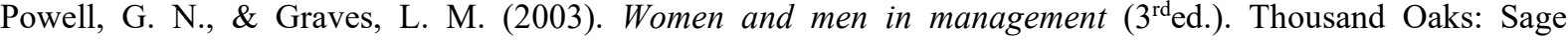
publications. Retrieved October $10^{\text {th }}, 2017$, Accessed: https://books.google.lk/books/about/Women and Men in Management.html.

Ramdhony, D., Oogarah-Hanuman, V., \& Somir, N. (2013). Career Progression of Women in Accounting the Case of Mauritius. International Journal of Humanities and Applied Science, 2(1), 22-28.

Ridgeway, C. L. (2011). Framed by Gender: How gender inequality persists in the modern world. United States of America: Oxford University Press.

Rigney, D. (2011). Boys vs. girls. Contexts, 10(4), 78-79. Retrieved March 22nd. 2018, fromhttp://journals.sagepub.com/doi/pdf/10.1177/1536504211427893

Rowe, J. L. (2014). Gender and Career Success in Public Accounting. Honors Theses. Paper 215

Silva, J. C., Magro, C. B. D., \& Silva, M. A. (2016). Gender inequality in accounting profession from the perspective of the glass ceiling. Race, Joacaba, 15(2),447-474.

Silva, J. C., Magro, C. B. D., Gorla, M. C., \& Silva, M. Z. (2018). Glass ceiling in the accounting profession: Evidence in Brazilian companies. Contaduría y Administración, 63(2), 2018, 1-23

Sri Lanka Labour Force Statistics Quarterly Bulletin. (n.d.). Retrieved October 12th, 2017, Accessed: http://www.statistics.gov.lk/samplesurvey/LFS_Q1_Bulletin_WEB_2016_final.pdf

Toffanin, T. (2009). Gender inequality in work-life balance. European Observatory of Working Life. Retrieved 
February 20, 2018, Accessed:

https://www.eurofound.europa.eu/observatories/eurwork/articles/quality-of-life/gender-inequality-in-worklife-balance.

Ud-Din, N.,Cheng, X., \& Nazneen, S. (2018) Women's skills and career advancement: a review of gender (in)equality in an accounting workplace. Economic Research-Ekonomska Istraživanja, 31(1), 1512-1525.

Whiting, R. H., \& Wright, C. (2001). Explaining gender inequity in the New Zealand accounting profession. British Accounting review, 33, 191-222.

Wirth, L. (2001). Breaking through the glass ceiling: women in management. Geneva: International Labour Office. 